Journal of Management and Economic Studies

2019, 1(1): 34-47 DOI: 10.26677/TR1010.2019.59

Journal Homepage: https://www.jomaes.org

\title{
Subsidy Regime in Nigeria, 1999-2014
}

\author{
Eme, Okechukwu Innocent \\ Department of Public Administration and Local Government, University of Nigeria, Nsukka \\ okechukwu.eme@unn.edu.ng \\ Ugwu Christain Chibuike \\ Department of Public Administration and Local Government, University of Nigeria, Nsukka
}

\section{Asogwa Maxmius}

Department of Public Administration and Local Government, University of Nigeria, Nsukka

\begin{abstract}
This study examined the socio-economic of subsidy regime in Nigeria between 1999 and 2014 . The researchers investigated the negative and positive effects of the subsidy policy on the masses in order to examine how the policy has properly impacted on the life of the, the intended beneficiaries. Subsidy regime in Nigeria has been a policy that each government tries to pursue because Subsidy has become a policy tool of government by giving incentive to industries, agriculture, health, transport, education, and oil, in other to promote and develop the economy. These subsidies were meant to helping the masses to assess these facilities at their own convenience and at a reduced price. However, up until the time of the study, the masses have not felt the impact of policy in the economy because of lack of proper consultation. The research methodology used for the study is documentary. The study found out that the policy is characterised among others by corruption and loss of revenue by the government among others. Recommendations were made on how to make the policy yield positive results in other to achieve its objectives in Nigeria.
\end{abstract}

Keywords: Subsidy Regimes, Corruption , Nigeria, Policy \& Political System.

\section{Introduction}

Subsidy regime has become a policy framework that each government in Nigeria tries to pursue because subsidy has been seen as a management and policy tool of government's industrialization .. However, up until the time of writing this paper, majority of the populace have not felt the impact of this policy because of its top-bottom approach..

Amidst the level of corruption and uncertainty surrounding the bases, application, impact, and sustainability of the policy, various governments have continued to pursue the subsidy option without sound empirical insights for the intended beneficiaries such as the rural poor, small 
and medium scale investors who produce more than $70 \%$ of the nation's agricultural output. In the area of transport, the masses are still experiencing unbearable hardship in transport fares. The same experience is equally manifesting in the fields of education and health where quality education and health care services are above the poor in Nigeria.

If subsidy is continually been targeted improperly and disproportionately benefiting the nonpoor masses in Nigeria, it is imperative that the policy be reformed and re-tooled to become more socially effective. To achieve this objective, the second section of the paper examined conceptual issue- subsidy. The third segment explored methodologies issues and theoretical framework of analysis. The next part discussed sin a thematic form the areas government have intervened. The following sections offered recommendations and conclude the paper.

\section{Contextualising Subsidy}

Putnam and Bartlett (1993) referred to subsidy as the transfer of economic resources by the government to the buyer or seller of goods or services that have the effect of either reducing the price paid, increasing the price received, or reducing the cost of production of the goods and services. According to (Keppler, 1995; Koplow, 1993; Michaelis, 1995; Pearce and Warford, 1993), subsidy is a form of government monetary support payment to a particular economic sector, institution, business, individual with the aim of promoting an activity or set of activities that the government deems beneficial to the economy in particular and to society at large .Indeed, this is one of the main roles that governments are created to perform: to encourage activities which, if left solely to market, would occur in unfavourable quantities.

Todaro et al(2009), Bakare (2012) and Ayogu(2012) share the same view on subsidy. For them, a subsidy is an assistance paid to a business or economic sector mainly by the government to prevent the decline of that industry or selling government services at a social cost.

But Agboeze (2012) pointed out a new dimension of subsidy debate. For him, it is a policy tool that addresses protectionism or trade barrier by making domestic goods and services artificially competitive against imports. This view equated subsidy with waiver policy.

Hornby, (2005) and Agu (2009) in their different studies defined the term within the context of waiver. Agu (2009:286) captured the views of these scholars when he defined the concept as a payment made by government to producers of certain goods and services, to enable them produce and sell at lower prices than they would otherwise. Agu was of the view that the policy helps to lower the market prices below the factor costs, so that consumers would have the privilege to pay less for the goods and services than they cost the producer to produce it. Critics of this view have posited that subsidy may distort markets, and can impose large economic costs.

What these definitions have in common is that subsidy is a device employed by governments to assist either the consumers or producers to consume or produce certain commodities at prices below the prevailing market prices. It is also an incentive given to either the consumers or producers to by government at the expense of expected revenue boom.

For our purpose, a subsidy amounts to any government expenditure that makes a resource

such as energy, agricultural products, education and transport appear cheaper to final consumers than its full economic cost. All such expenditures represent hidden costs of producing, converting and using a resource. 


\section{Methodology}

\section{Theoretical Framework}

System theory will be used as our theoretical framework of analysis. System theory is one of the most widely used theoretical framework by scholars and students respectively. This theory depends so much from the works of the following scholars-Ludwig von Bertalanffy (1950), Talcott Parson (1951) and David Easton ( 1965a \&1965b), among others. They conceived a system as a set of elements that are linked in interaction and share some common features. This includes any grouping with any sort of the relationship, collection of people, etc. A system is regarded as a phenomenon (be it physical, biological or social), is conceived as an organized purposeful whole, composed of structurally identifiable boundaries from the supra-system (the Environment) in which it interacts.

According to Russel Ackoft (1972) quoted in Enwerem (2009:51), the systems theory is an important transition from the mechanistic concept of social reality which sought to explain a phenomenon from the standpoint of its constituent units as a the part in terms of the whole. In addition, he stated that a system is a whole, which cannot be taken apart without the loss of its essential characteristics. The characteristics include:

1) A system has a set of objectives, which the entity seeks to achieve, and without it cannot exist.

2) A hierarchy of inter-dependent units (sub system) which interact among themselves in other to achieve the system objectives.

3) Each sub -set of structure have roles to play, meaning that each sub-system has a defined and specialized role in the realization of the purpose of the system and sub-system roles are mutually reinforcing.

4) An input transforming technology processes and techniques by which resource inputs extracted from within, has implication for systems perspective and effectiveness through feedback mechanism.

5) A boundary which excludes the plethora of other structures that define the threshold of transformations among the universe of system;

6) An environment meaning the larger context in which the system is situated a context in which it engages in mutual transactions through the agency of input and output.

Accordingly, system theory assumed that,

- The society makes demands as society also renders supports

- The system processes the demand.

- They are a dynamic Environment.

- They are always a feedback to the system by the society (Anderson,1997, Dye,2008 \& Jones, 1977) 
Figure: A Model of the Political System

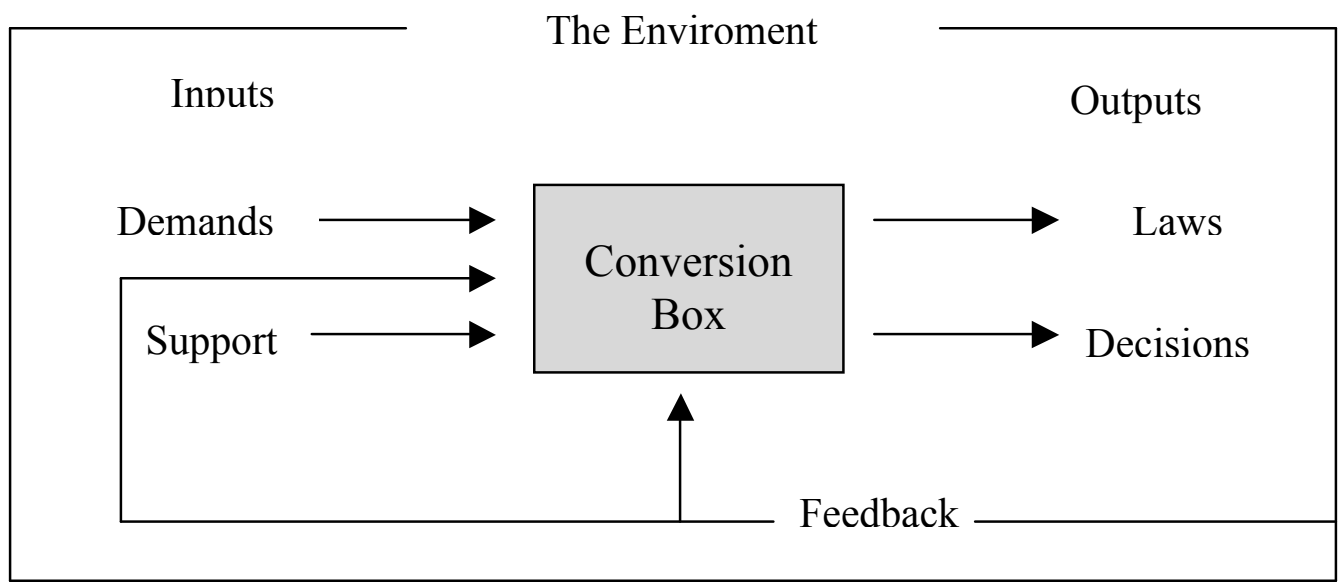

Source: Anderson, J. E (1975), Public Policy-Making, New York: Praeger Publishers

Inputs into the political system from the environment consists of inputs of demands and supports.The former are the claims for action that individuals and groups make to satisfy their interests and values while the latter are gotten when groups and individuals support governments either by voting them in during elections, pay their taxes, obey laws, and otherwise accept the decisions and actions undertaken by the political system in response to demands. The amount of support for a political system suggests the extent to which it is regarded as legitimate, or as authoritative and binding on its citizens.

Outputs in system theory are processed information which include laws, rules, judicial decisions, and the like. Regarded as the authoritative allocations of values, they constitute public policy. The concept of feedback refers to the responses government from the people when policies are made. It may generate support or crises that will require another policy to correct.

The usefulness of system theory in studying any public policy is limited by its highly general and abstract nature. It does not moreover; say much about the procedures and process by which decisions are arrived at within the "black box" called the conversion chamber. Indeed, systems theory depicts government as simply responding to demands made upon it, and its results are sometimes characterized as "input-output studies,". Nonetheless, this approach can be helpful in organizing inquiry into policy formulation. It also alerts us to some important dimensions of the political process. For instance, How do inputs from the environment affect the content of public policy and the operation of the political system? How in turn does public policy affect the environment and sub-sequent demands for policy action? How productive is the political system able to convert inputs of demand into public policy and preserve itself over time?

\section{Application of the Theory}

Nigeria as a political entity has environment were groups and government both make demand. Governments demand the payment of taxes, be law abiding and support government programmes, the people equally demand from governments accountability, and 
decisions which the citizen must abide in to show support to the governments. The conversion box will be the government, which is a sub-system of the system (Nigeria), where all problems are been brought to. All the issues been brought in by all sectors of the economy are been iron out in line with the government policies of the country which is highly dependent on the policy direction and capability of the government in power. For instance during the Jonathan's regime his government brought out the issue of tax wavier which his predecessors also did. Wavier is the charging and waiving of customs duty, an integral part of the tax system in any country which a government routinely use in her attempt to influence economic and industrial development with the aim of furthering her national objectives (Weber, 1994).

As Okeke (2001) posited, in several developing counties, government provide tax incentives, which include duty waivers, to encourage capital formation in selected industries. But in order to help achieve this objective, such incentive must meet the characteristics of a good tax system, which include fairness, transparency and even handed application (Duanjie 2004).

The then President Jonathan administration grossly abused waivers to businesses. In September 2011, for instance the former Minister of Finance announced that the power to grant waivers have been transferred from the President to the Economic Team in order to avoid further abuses. Such a pronouncement meant that the Government was simply replacing one illegality with another illegality. This is so because there is no mention of the "Economic Team" in the laws governing the granting of custom duty waivers in Nigeria. On 30th November, 2011, Daily Trust exclusively reported that the Federal Government granted rice and palm oil import duty waivers amounting to about N150 billion to 10 companies. With one of them securing the duty write offs 164 times since February 2011. (Daily trust, 30 November 2011). Later that year, the President directed that no import waiver should grant in the 2012 fiscal year. (Punch 29 Oct, 2012). This like all previous policy directives did not stand the test of time.

The output of the process occurred in the conversion box turn out to be negative as we have mentioned about the wavier. If a government adopts a policy and at the long run things gets bad or says bad politicians hijack it, the people will perceive danger and it will lead to dissatisfaction among the people. When the government fails to bring out policies that can benefit the people the resultant effect will be agitation. This output determines the next input through the feedback the feedback loop mechanism.

\section{Subsidy Regime in Nigeria: A Thematic Exposition}

The history of subsidy regime in Nigeria has history that dates back to the era of national development plan. To do justice to the discourse to the sectoral analysis, we are going to discuss them in themes:

\section{The Agricultural Sector}

Before the discovery of oil in Nigeria, agriculture was the mainstay of the Nigerian economy. It provided food and employment for the populace, raw materials for industries and revenue and foreign exchange for the Government. Largely there are four historical epochs in Nigeria. The first epoch was 1960-69 during which the developmental approach was essentially laissez-faire. Agriculture was mainly in the hands of small scale subsistent operators. Government involvement was limited to the development of research institutions for agricultural research and product marketing (marketing and commodity boards). The second phase was the period of intensive state control of agricultural activities (1970-85). The third phase was the era of Structural Adjustment Programme and guided deregulation (1986-99) when government started promoting large scale farming with limited support for subsistent farmer. Land was deregulated. The fourth phase is the era of reform under a democratic 
government in which the economy is conceived to be market-oriented and private sector driven.

The period had witnessed policies in many critical areas including agricultural credit guarantee, granting of subsidy on fertilizer and other agriculture inputs, regulation of food import through appropriate tariff policies, establishment, and abolition of commodity boards, establishment of commodity marketing companies, and land reform. Under the era transformation agenda instituted by the Jonathan administration (2011-15), emphasis is on the development of agricultural commodity value chains, transformation of agricultural marketing, reform of agricultural insurance, improved agricultural finance through the Nigerian incentivebased risk sharing system for agricultural lending and establishment of microfinance banks for agriculture.

\section{Education Sector}

Nigeria's independence education system and policy was characterized by series of committees and conferences. Concrete steps toward curriculum reforms started in 1966 by the National Education Research Council (NERC) under Chief Awokoya (Sofolahan, 1987). In September 1969, the curriculum reform conference debated on appropriate curriculum contents and problems in Nigeria's education system. Another conference held in 1973 led to the formulation and production of the National Policy on Education in 1977and as revised in 1981 and 2004 respectively. The production of this document and the eventual take-off of the policy in 1982 in some states of the country, marked the end of the post-independence piece-meal and rather disjointed adjustments to the colonial education heritage bequeathed on Nigeria by the British.

The education system based on the National Policy on Education (NPE) document of1977 (last revised in 2004). This policy document addressed the issues of imbalance in the provision of education with regard to access, quality of resources and girls' education. The policy organized education curriculum into 6 years of primary education, 3 years of junior secondary school, 3 years of senior secondary education and 4 years of university/polytechnic/ college education.

Government initiatives to reform the education system in the 1990s included the revision of the National Policy on Education document and two studies of the education sector was conducted on how to improve education. The first study "A Situation Analysis Policy Study" (SAPA) conducted in cooperation with the United Nation Children's Education Fund (UNICEF). The study was undertaken to help analyze the factors inhibiting access to education, and factors that affect the quality of education. The study was conducted between 1991 and 1992. The second study was conducted in 1997 and was aimed at assessing learning achievements of Nigerian primary school children at level four. The results of this study indicated that the children lacked basic numeracy and literacy competencies.

Another initiative by the government during this period was the introduction of a free and compulsory nine-year schooling program in 1992. It covered primary education and junior secondary education. The main objective of the program was to ensure that there was a smooth transition from primary education to junior secondary school. It also aimed at ensuring that learners remain in school long enough to acquire basic and life skills.

In 1996 another initiative was taken by the government in the area of funding of education. The initiative, FGN/ODA Nigeria community education programme aimed at addressing the needs of rural communities in three states of the Federation, namely, Abia, Bauchi, and Akwa-Ibom and to meet the needs of the nomadic communities in the North Eastern part of the country. The objective of this initiative is to increase equality and access to education especially women 
and girls in the targeted communities. Other initiatives are in the restructuring of education funding arrangements.

In the case of secondary schools, between 1989-1994 the Federal Government was funding about 66 secondary unity schools and the rest were funded by the State governments. The administration, management and funding of the schools are shared between the State Ministries of Education, the National Secondary Education Commission and other agencies as prescribed in the legislation (Moja2000). Education at this level is free of tuition although students were expected to pay levies as contribution to the costs of running the schools. Education at this level has two purposes. One, is to prepare pupils to exit school with the necessary skills to find employment, and the other is to prepare them to continue with academic careers in higher education.

The Federal government is the major financier of higher education in Nigeria.

Government funding of education has been inadequate. The funding of education is shared among different levels of government and supplemented by funds from other sources such as businesses, community organizations, and levies charged to parents. The revenue collected through fees constitutes an insignificant proportion of the revenue of the institutions. Inadequate funding of education has been one of the most significant causes of the low quality of much of the education offered at all levels. Funding allocations have been in flux during the last decade. Overall, there has been a drop in the funding level of education. The table 1 below summarizes the year - by - year allocation to the sector between $1999-2016$.

Table 1: Summarizes the year - by - year allocation to the sector between 1999 - 2016

\begin{tabular}{|l|l|l|}
\hline Year & Allocation in billion & Percentage \\
\hline 1999 & N23.047 & $11.2 \%$ \\
\hline 2000 & N44.225 & $8.3 \%$ \\
\hline 2001 & N39.885 & $7.0 \%$ \\
\hline 2002 & N100.2 & $5.9 \%$ \\
\hline 2003 & N64.76 & $11.8 \%$ \\
\hline 2004 & N72.22 & $7.8 \%$ \\
\hline 2005 & N92.59 & $8.3 \%$ \\
\hline 2006 & N166.6 & $8.7 \%$ \\
\hline 2007 & N137.48 & $6.07 \%$ \\
\hline 2008 & $\mathrm{~N} 210.00$ & $13 \%$ \\
\hline 2009 & N183.36 & $13 \%$ \\
\hline 2010 & N249.08 & $12 \%$ \\
\hline 2011 & N356.51 & $7.94 \%$ \\
\hline 2012 & N400.15 & $8.43 \%$ \\
\hline 2013 & N427.52 & $8.7 \%$ \\
\hline 2014 & N493.45 & - \\
\hline 2015 & N292,242,784,654 & - \\
\hline 2016 & $500 b n$ & - \\
\hline
\end{tabular}

Sources: From the authors and collections from the Budget office, CBN \&NBS

Despite the increase in allocations, in real terms the recurrent financing per student has declined by more than 30\%( ASUU, UNN Branch 2009) while student enrollment increased by $88 \%$. There is a huge gap between the NUC parameters for funding and Federal government allocations to higher education. Two facts emerge from this table. 
One is Nigeria's paltry allocation to Education. The second is that, even by standard of African countries which share the same economic and social features with us, Nigeria scored lowest in her budget allocations to Education.

The re- launch of Universal Basic Education in 1999 was aimed at providing free universal basic education for all, to enable all citizens to acquire appropriate levels of literacy, numeracy, communicative, manipulative and life skills. The intention was to provide nine years of compulsory education that would span primary and secondary levels. Access to basic education as a national priority includes literacy and adult education, science and vocational training. To implement the scheme, government has established two committees as part of its strategy to ensure that the goal is achieved. The Coordinating Committee and the Technical Committee are to be headed by the Vice President and the Minister of Education respectively. The plans include public information and community mobilization, provision of resources and the setting up of mechanisms to facilitate implementation of the programs.

From 1999-2016 data gotten from Statistics of education budgets in Nigeria show how the federal government has been subsidizing the tertiary institution in Nigeria. Under the transformation agenda, Priority policies for the development of education include:

1) Promotion of primary enrolment of all children of school going age irrespective of the income profile of the parents

2) Provision of infrastructures such as classrooms across all levels of education to ease overcrowding, increase access, and reduction of pupils'/teacher ratio

3) Enhancement of the efficiency, resourcefulness, and competence of teachers and other educational personnel through training, capacity building, and motivation

To actualize the goal of Transformation Agenda in the education sector, the Federal Ministry of Education drawn a 4-Year Strategic Plan $(2011$ - 2015) for the development of the sector. The plan has six (6) focal areas:

- Access and equity;

- Standard and quality assurance;

- Strengthening the institutional management of education;

- Teacher education and development;

- Technical and vocational education and training

- Funding, partnerships, resource mobilization and utilization( Jonathan,2011)

In a bid to revamp the educational sector after the non-implementation of the 2009 agreement which brought in the 2012 strike in the universities, the Federal Government on January 2012 signed a memorandum of understanding (MoU) with ASUU and renewed its commitment and assurances to full implementation of the 2009 Agreement as articulated by Otobo(2009:27) are as follows:

i. Funding requirement in revitalizing the Nigeria universities: Government reaffirms its commitment to the revitalization of Nigerian universities through budgetary and no budgetary sources of funds. Government will immediately stimulate the process with the sum of N100billionand will build this up to a yearly sum of N400 billion in the next three (3) years. These interventions will be based on identified prioritized needs.

ii. Federal government assistance to state school: The state universities shall continue to enjoy federal special and other statutory interventions.

iii. Progressive increase of annual budgetary allocation to education to $26 \%$ between 2009 and 2020 Government will improve significantly the budgetary allocation to education from 
2013 to 2020.

iv. Earned Academic Allowances: Government accepts in principle the payment of Earned Academic Allowances (EAA). However, there is need to work out practical and sustainable ways to do this. Consequently, the mandate of the Implementation Monitoring Committee (IMC) has been expanded to include proposing practical and sustainable ways of paying the Earned Academic Allowances and the report is expected in 60 days. Government shall direct the universities to support internal staff development of all those not covered under Tertiary Education Trust Fund (TET)fund intervention on capacity building.

v. Amendment of the pension/retirement age of academics on the professorial cadre from 65 to 70 years As soon as the legislative procedures for the Bill on seventy years retirement age for academics at the professorial cadre are concluded, the president shall assent to it not later than the end of February 2012.

vi. Establishment of Pension Fund Administrator: Government directed the Implementation Monitoring Committee (IMC) to take all necessary steps to register Nigerian university pension management committee (NUPEMCO) within three (3) months. Where the IMC has difficulties, it should refer the matter to the Government for necessary action.

Vii. University Governing Council: Government undertakes to reinstate Governing Councils of various universities on or before February 12, 2012, but may make changes in external membership where it deems necessary. The tenure of the Councils thus reinstated ends in February 2013.

viii. Transfer of Federal Government landed property to universities: Universities shall form a University Property Holding Company, which shall among other things, participates in the acquisition, management, and concession of government properties.

ix. Setting up of research and development units by companies operating in Nigeria and teaching and research equipment Government will encourage companies operating in Nigeria to collaborate closely with Nigerian universities in setting up research and development units.

x. The Budget Monitoring Committee (BMC) Each council shall set up a Budget Monitoring Committee (BMC), which shall monitor the effective use of funds in each university. BMC shall through the Governing Council, send its report on project execution, budget performance, and financial discipline to the Implementation Monitoring Committee quarterly.

xi. Expansion of the implementing monitoring committee the implementing committee will be expanded to include one representative each of the ministry of finance, Ministry of National Planning and the Budget Office.

In order to ensure effective overall monitoring of the implementation of the FGN/ASUU agreement, Government shall meet with the expanded IMC on a quarterly basis to assess progress( Sobowale,2009, ASUU, UNN Branch 2009,ASUU, UNN Branch, 2012,\&ASUU, UNN Branch 2016).

\section{Transport Sector}

After Nigeria's political independence, different regional and city governments began to establish public transport systems for developmental economic purposes. These include the Ibadan City Bus Service, the North Western State Transport Corporation (operating then as Kano Line), Kwara Line, and Plateau State Transport Corporations among others. 
Unfortunately, most of these transport lines collapsed between the second half of 1970s and early 1980s due to mismanagement and fraud (Adeniji, 2002) However, from the mid-1980s, other government owned public transport companies were established in Lagos, Kaduna, Port Harcourt, Kwara, Rivers, Oyo, and Edo States. With the exception of Lagos State Transport Corporation (LSTC) these transport corporations also collapsed and were closed down completely as a result of corruption, Financial impropriety, inadequate government financial support, lack of qualified staff, political interference, and uncontrolled competition from private transport operators((Adeneji,2000) .These State- Owned transport companies operate arbitrarily and increase transport fares without control or regulation (Daramola, 2003) in pursuit of greater profit, business expansion, and as a mechanism for paying back loans within the shortest period to avoid interest payment. According to Filani (2002), and Filani, (2003), the consequences of the above-uncontrolled extortion, lack of enough vehicles to meet commuters demand, sub-standard and unorganized operational system led to:

1. Unprecedented socio-economic hardship on the citizens;

2. Steady decline in the level of motorization by 50percent between 1990 and 1998 thereby causing acute shortage of transport services

3. The use of used and discarded vehicles (a.k.a 'tokumbo') imported from Europe and America

4. Environmental pollution; and

5. Perverse scourge of road traffic accident that have continued to claim hundreds of lives (Federal Republic of Nigeria,1996).

Consequently, these problems led to an increase in demand for a new transport policy. The of the Federal Urban Mass Transit Programme (FUMTP) was established in January 1988 to address the socio-economic and mobility frustrations and hardships experienced by the citizens and communities across cities in Nigeria (Kontagora, 1988\& Ogbazi,1989).

This intervention brought into being State-owned mass transit companies across the states of the federation a way of improving the public transport at these levels. FUMTP offered grantaided facilities to the states in the form of maintenance; workshop equipment's; mobile workshop and tools; traffic improvement measures. The Federal Government injected over 2000 Federal Assisted Buses into the public transport service network across the states. About $85 \%$ of those buses were given to the state-owned companies under concessionary loan conditions. The remaining $15 \%$ of the buses was distributed to Federal Colleges, Universities, and other Tertiary Institutions and specialized Agencies as grants (Filani,2003 and Sunday Concord, 1989).

The public mass transit system was better organized, boost of better trained staff and maintenance facilities than most of the private sector operators. Their services are often provided on fixed routes, and their fares are relatively cheaper than those provided by private sector operators. They have service schedules, although in practice are rarely followed because of the inadequacy of vehicles, declining fleet utilization rates, growing competition from private operators, poor traffic management, and congestion especially during peak travel periods (Umar, 2003).

The success recorded by FUMTA and its challenges led to the emergence of another transportation policy in 1993 to strengthen the Mass Transit Programme. According to World Bank (1996), the general objectives of the new transport policy include; adequacy, economic and financial efficiency, safety, reliability and national self-reliance. However, its major pitfall was that there was no approved policy guideline, sanction, and deadline for its 
implementation. Consequently, the NTP had little or no influence on the government's actions in the transport industry.

In response to these challenges, the federal government articulated a new transport policy in its National Economic Empowerment Development Strategy (NEEDS) programme. The NEEDS transport policy envisaged a transport development strategy that is private sector driven with government guaranteed safe environment that addresses the issues of wealth creation, employment generation and poverty reduction (FGN, 2010).

Scholars like Aderemo(2004) and Afukaar (2001) noted that in spite of all these reforms, the prices of transport facilities, vehicles, and spare parts such as tires, tubes, fuel, and lubricants have continued to increase leading to some private public transport companies fizzling out while most of the government owned transport companies remained 'a ghost' of themselves.

According to Thisdayonline.com of August 9, 2012, government intervened in the transport industry by in 2012 after the anti-subsidy strike by releasing 1,600 mass transit buses [although only 1,100 buses were released] to strengthen the programme and ease mobility problems. The Federal Government, 36 state governments, 774 local governments, the Central Bank of Nigeria, and several commercial banks were involved in this new partnership. No technical or academic research work has evaluated the distribution of these buses, their impact on the declining mass transit services and the socio-economic problems caused by the fuel subsidy removal.

\section{Recommendations}

Based on the study's findings, the study suggested the following recommendations: -

The Federal government policy of subsiding other sectors such as the transport, agriculture, housing, education and industries would add value to the lives of Nigerians. The Lagos state model of Public - Private Partnership (PPP) initiatives should serve as model.

Savings from the excess crude account should and other government savings such as the Sovereign wealth fund should be used by the federal government for infrastructural development.

The government must come up with policies that will compensate Nigerians developmentally and utilize the savings to checkmate inflation.

The government should work on the regulatory agencies for effective service delivery where the rights of the citizens must be protected.

The government at all levels should rebuild the people's trust in its by: - cushioning the effects of the fuel subsidy removal, curbing the excesses of the three tiers of government, investigating and bringing to book all those corrupt officials/economic saboteurs/cabal that squandered the fuel subsidy and waiver largesse.

The Economic and Financial Crimes Commission (EFCC) and other anti-corruption agencies should always be at alert and make sure those responsible for corruption, abuse of office and power and mis-management of fund are brought to book. They should be allowed full access to relevant government information to aid their work.

\section{Conclusion}

This paper summarised in a thematic form the subsidy regime between 1999 and 2014. The selected and focused areas include the agriculture, transport and education sectors and found out the benefits and challenges of the subsidy regime. The study suggested among other that the federal government should articulate good policy frameworks in these areas in order to address the gaps and challenges in these areas. They should equally bring to book those who 
mis-manage the subsidies in the past to book. The paper, therefore concluded by positing that if the finding and recommendations that the researchers have brought out could be followed, we shall see a new dimension of subsidy policy affecting the masses positively.

\section{REFERENCES}

Ackoff R. (1976). Purposeful System Theory, New York: McMillan Publishing Company.

Adeniji, K. (2000), "Public Transportation: A Basic need in Nigeria”, AITTC Review No. 46. P. 2

Adeniji, K. (2002), "Transport challenge in Nigeria in the next two decades". Keynotes address delivered at the $5^{\text {th }}$ National council on transport organized by Federal Ministry of Transport, Abuja.

Aderemo A.I. (2004), Urban transport and The Environment. In Vandu C. Ogunsanya, A.A. and Sumaila, A.G. (eds): Perspectives on urban transportation in Nigeria p.p. 101-120.

Afukaar, F.A. (2001), A review of successful transport and home injury interventions to guide developing countries. Social Science Medial Journal. 43:1551-1560.

Agboeze, M.U. (2012). "Fuel Subsidy Removal and Sustainable Development", Journal of International Studies in the Humanities, October, Vol. 9.

Agu, C.C., (2009). Principles of Economics, Enugu: Immaculate Publication.

Akintunde, .K. (2009), "Citadels of Decay", Newswatch, October 5, Pp.10 -12.

Aluta. Conituna", The Guardian on Sunday, September 27, p. 27

Anderson J.E. (1997), Public Policy Making, New York: Houghton Mifflin Company.

Ayogu G.I. (2012). "Fuel Subsidy Removal and Sustainable Development" Journal of International Studies in the Humanities, October, Vol.9.

Bakare, T. (2012). "Much Ado about Fuel Subsidy", retrieved on January 17, 2012 from the world wide web http://www.vanguardngr.com/2012/01/much-ado-about-fuel-subsidy/.

Bassey, J. (2009) "Crippled by ASUU, frustrated by NUT", Business Day, Monday, 05; October, pp48-9.

Bertalanffy, L. V. (1950). "General System Theory", in David Singer(ed.),Human Behaviour \& International Politics New York: George Braziller.

Bolade, T. (1991), "Two years of urban Mass Transit operations in Nigeria: Reflections in Accident and safety perspectives" in Bolade t. and Ogunsanya (eds) Accident control and safety Measures in Mass Transit Operations in Nigeria. Ibadan University Press pp. 75-86.

Daily Trust, 'Nigeria: Rice, Palm Oil Imports- FG Grants N150 Billion Waivers to 10 Firms in 10 Months' (November 30, 2011) http://allafrica.com/stories/201111300315.html> (January 10, 2013).

Daramola, A.Y. (2003), "Innovative options for financing Transport infrastructure in Nigeria". In Nisereel, The Magazine of the Nigerian Institute of social and Economic Research, Nos. $4 \mathcal{E}$ 5, December. Ibadan.

David, R. (1993). “Determinants of FDI Incentive Preferences of MNEs", Journal of International Business Studies 24 (2), Pp. 335-355. 
Duanjie C. (2004). "Reforming the Taxation Incentive Program in Jordan: Analysis and Recommendations", Paper Number 0412, Pp.5-10.

Dye, T.R. (2008), Understanding Public Policy, (Eleventh Edition), New Jersey: Pearson.

Easton, D. ( 1965). A Framework of Political Analysis, New jersey: Prentice Hall Inc..

Easton, D. ( 1965). A Systems Analysis of Political Life, New York: Wiley Publishers.

Ezeani, E. O (2006) Fundamentals Of Public Administration. Enugu: SNAAP Press Ltd.

Federal Republic of Nigeria (1979 Constitution) (1979), Lagos: Government Printers.

Federal Republic of Nigeria (1996) National Urban Transport Policy for Nigeria(. Draft Policy), Abuja: Federal Urban Mass Transit Agency.

Federal Republic of Nigeria (1999 Constitution). Abuja: Government Printers.

Federal Republic of Nigeria (2010) National Urban Transport Policy for Nigeria(. Draft Policy), Abuja: Federal Urban Mass Transit Agency.

Filani, M.O. (2002), "Long term development of the Mass Transit program in Nigeria" Paper presented at the $10^{\text {th }}$ Anniversary of the Federal Urban Mass Transit Agency (FUMTA). Abuja.

Filani, M.O. (2003), "Advancing the cause of private participation in the Road Transport sub-sector in Nigeria". A paper devered at the $10^{\text {th }}$ anniversary celebration of the Associated Bus Company (ABC) Ltd, on May 14, at Ikeja.

Frank, F. and Jean-François, W. (1996). “Are Tax Incentives Biased against Small Firms in Thailand", The Journal of Developing Areas, 31, 1.

Hornby, A.S., (2005). Oxford Advanced Learners Dictionary, New York: Oxford.

http://ndn.nigeriadailynews.com/templates/?a=11944> (January 11, 2013).

http://www.thenigerianvoice.com/nvprint/525/6/revealed-how-dangote-tore-danjuma-andobasanjo-apa.html> (December 11, 2012).

Ibeleme, E. (2009) “Still Below Standard”, Nigerian News World, October 12,Pp21 - 23.

Jones C.O. (1977), An Introduction to the Study of Public Policy, (Second Edition), North Sctituate, Massachusets: Duxbury Press.

Keppler, J. (1995). Public Goods, Infrastructure, Externalities and Subsidies. Paris: Organisation for Economic Cooperation and Development.

Koplow, D. (1993). Federal Energy Subsidies: Energy, Environmental and Fiscal Impacts. Washington DC, USA: Alliance to Save Energy.

MacRae, (JR) D. \& Wilde J.A. (1979), Policy Analysis for Public Decisions, North Scituate Massachusetts: Duxbury Press.

Madike, I. (2009), “The crumbling Ivory Towers”, Saturday Independent, June 27, pp B3 - B5.

Michaelis, L. (1995). Environmental Implications of Subsidies to Energy and Transport. Paris: Organisation for Economic Cooperation and Development.

Nigeria Daily News, 'How Indian Firm Abuses Import Duty Waiver' (August 31, 2008).

Okeke, I. (2001), Theory and Practice of Public Policy Analysis the Nigerian Perspective, Enugu: Bismark Publications. 
Olanrewaju, K., Folorunso, A and Bakare, E. (2009) "Education:49 years of failed expectation", Nigerian Compass, Wednesday, September 30,P.23.

Omokhodion, L.A. (2008) "ASUU and the Products of Strikes", Thursday, Thisday, February 8, P.24.

Otobo, D. (2009) “Beyond Thomas Olusanya and His Statistical

Panayotou, T. (1993). Green Markets. San Francisco, California, USA: Institute for Contemporary Studies Press.

Parson, T (1951). "The Theory of Human Behavior in its Individual and Social Aspects", The American Sociologist, Vol. 27. No. 4, Pp.13-23.

Pearce, D.W. and Warford, J.J. (1993). World Without End: Economics, Environment and Sustainable Development. San Francisco, California, USA: Oxford University Press.

Plante, M. (2013). “The Long-run Macroeconomic Impacts of Fuel Subsidies," Journal of Development Economics, 107, Pp. 129-143.

See Nigerian Voice, 'Revealed: How Dangote tore Danjuma and Obasanjo Apart,' (June 27, 2009).

See Punch Newspaper downloaded on October 29, 2012 from http://beta.jangola.com/news/business/1498-fg-stops-import-dutywaiver.html September.

Sobowale, D. (2009), "ASUU and FG: A national tragedy", Sunday vanguard, September 27, p.15

Sunday Concord, 'Mass Transit Without Tears', August 27, 1989, p. 25.

The Punch Newspaper (2008). Abuse of Waiver.

Thisday, 'Nigeria: Yar'Adua Suspends Waivers, Tax Exemptions', (August 24, 2007). http://taxjusticeafrica.blogspot.com/2007/08/nigeria-yaradua-suspends-waiverstax.html> (December 11, 2012).

Thisday, 'Nigeria: Yar'Adua Suspends Waivers, Tax Exemptions', (August 24, 2007). http://taxjusticeafrica.blogspot.com/2007/08/nigeria-yaradua-suspends-waiverstax.html> (December 11, 2012).

Todaro M.P. and Smith S.C. (2009). "Economic Development", 10 $10^{\text {th }}$ edition, Addison Wesley: p. 839, ISBN 978-0-321-48573-1. Retrieved from http://en.wikipedia.org/wiki/subsidy.

Weber, P.( 1994), Net Loss: Fish, Jobs and the Marine Environment. Washington DC, USA: Worldwatch Institute.

World Bank Report (1990),Nigeria: Urban Transport in Crisis, Washington DC, USA: World Bank. 